\title{
Review: counselling and education reduce cardiovascular risk factors but not mortality
}

Ebrahim S, Davey Smith G. Multiple risk factor interventions for primary prevention of coronary heart disease. (Cochrane Review, latest version 24 February 1999). In: Cochrane Library. Oxford: Update Software.

QUESTION: In people without evidence of established cardiovascular disease, do counselling or educational interventions reduce cardiovascular risk factors, deaths from all causes, and deaths from coronary artery disease (CAD)?

\section{Data sources}

Studies were identified using Medline (1966 to April 1995), bibliographies of relevant studies, and by contacting experts.

\section{Study selection}

Studies were selected if they were randomised controlled trials with $\geq 6$ months of follow up of counselling or educational interventions with or without medications aimed at controlling $\geq 1$ cardiovascular risk factor (blood pressure, smoking, total blood cholesterol, physical activity, and diet) in people $\geqslant 40$ years of age without evidence of cardiovascular disease.

\section{Data extraction}

Data were extracted independently by 2 reviewers on methodological quality of the trials, patient baseline characteristics, and follow up. Outcomes were changes in blood pressure and total blood cholesterol, smoking, deaths from all causes, and deaths from CAD.

\section{Main results}

18 trials (140 245 patients) were included. Heterogeneity existed among the trials for all outcomes except CAD mortality. One reason for heterogeneity was the inclusion of trials that studied only hypertensive patients. Blood pressure, total blood cholesterol, and smoking prevalence were reduced in patients who received risk factor modification compared with patients who received no intervention or usual care (table). 10 trials included clinical

Risk factor intervention (Int) v no intervention for coronary artery disease $(C A D)^{*}$

\begin{tabular}{|c|c|c|c|c|}
\hline \multicolumn{3}{|l|}{$\begin{array}{l}\text { Outcomes } \\
\text { (follow up } \\
\text { range } 6 \text { mo to } \\
12 \mathrm{y} \text { ) }\end{array}$} & \multicolumn{2}{|l|}{$\begin{array}{l}\text { Weighted } \\
\text { mean } \\
\text { decrease } \\
(95 \% \mathrm{CI})\end{array}$} \\
\hline \multicolumn{3}{|c|}{$\begin{array}{l}\text { Systolic blood pressure } \\
(\mathrm{mm} \mathrm{Hg})\end{array}$} & \multicolumn{2}{|l|}{$\begin{array}{l}3.3 \\
(1.9 \text { to } 4.7)\end{array}$} \\
\hline \multicolumn{3}{|c|}{$\begin{array}{l}\text { Diastolic blood pressure } \\
\qquad(\mathrm{mm} \mathrm{Hg})\end{array}$} & \multicolumn{2}{|c|}{$\begin{array}{l}2.2 \\
(1.3 \text { to } 3.1)\end{array}$} \\
\hline \multicolumn{3}{|c|}{$\begin{array}{l}\text { Total blood cholesterol } \\
(\mathrm{mmol} / \mathrm{l})\end{array}$} & \multicolumn{2}{|c|}{$\begin{array}{l}0.16 \\
(0.09 \text { to } 0.24)\end{array}$} \\
\hline & Int & No int & $\begin{array}{l}\text { RRR } \\
\text { (CI) }\end{array}$ & $\begin{array}{l}\text { NNT } \\
\text { (CI) }\end{array}$ \\
\hline $\begin{array}{l}\text { Smoking } \\
\text { prevalence }\end{array}$ & $34.5 \%$ & $38 \%$ & $\begin{array}{l}10 \% \\
(2 \text { to } 17)\end{array}$ & $\begin{array}{l}29 \\
(14 \text { to } 200)\end{array}$ \\
\hline $\begin{array}{l}\text { All cause } \\
\text { mortality }\end{array}$ & $7.1 \%$ & $7.2 \%$ & $\begin{array}{l}5 \% \\
(-4 \text { to } 13)\end{array}$ & $\begin{array}{l}\text { Not } \\
\text { significant }\end{array}$ \\
\hline CAD mortality & $2.5 \%$ & $2.6 \%$ & $\begin{array}{l}4 \% \\
(-4 \text { to } 11)\end{array}$ & $\begin{array}{l}\text { Not } \\
\text { significant }\end{array}$ \\
\hline
\end{tabular}

${ }^{*}$ Random effects model used for all outcomes except CAD mortality. Abbreviations defined in glossary; NNT calculated from data in article. outcomes. Deaths from all causes or from CAD were not reduced by risk factor modification (table).

\section{Conclusion}

In people without evidence of established cardiovascular disease, multiple risk factor interventions consisting of counselling or educational interventions show modest reductions in blood pressure, blood cholesterol, and smoking prevalence, but not deaths from all causes or from coronary artery disease.

\section{COMMENTARY}

The review by Ebrahim and Davey Smith will be of particular interest to nurses working in primary or community care settings and in health promotion or public health. The review is likely to have identified and included all the relevant, good quality studies.

The results indicate that multiple risk factor interventions with individuals and families produce only modest (and probably then overstated) benefits for the general population. However, such strategies may have an important benefit in terms of risk reduction for the subgroup of people at high risk of or with pre-existing CAD.

No cost effectiveness analysis was done, but other economic analyses can give us pointers. For example, the cost effectiveness of statins for lowering cholesterol varies enormously depending on patient risk. ${ }^{.}$Simple actions that non-specialists can take to promote smoking cessation effectively are highly cost effective. ${ }^{2}$

Nurses in primary practice settings should therefore target their CAD prevention work to those people who are already at high risk, paying particular attention to smoking cessation, while taking into account the likely differing risk profile of men and women. ${ }^{3}$ The "prevention paradox" implies that we should not expect too much from individual health education. ${ }^{4}$ Efforts to reduce $\mathrm{CAD}$ in the wider population should focus on fiscal and legislative change and community development that aims to improve the environmental context.

Mark Newman, RGN, MA, PGCHE Senior Lecturer

School of Health, Biological and Environmental Sciences Middlesex University \& Barnet \& Chase Farm Hospitals NHS Trust London, UK

1 Pharoah PD, Hollingworth W. Cost effectiveness of lowering cholesterol concentration with statins in patients with and without pre-existing coronary heart disease: life table method applied to health authority population. BMJ 1996;312:1443-8.

2 Fiore MC, Bailey WC, Cohen SJ, et al. Smoking cessation. Clinical practice guideline no 18. Rockville, MD: Agency for Health Care Policy and Research, 1996.

3 Meilahn EN, Becker RC, Corrao JM. Primary prevention of coronary heart disease in women. Cardiology 1995;86:286-98.

4 Rose G. Strategy of prevention: lessons from cardiovascular disease. BMJ (Clin Res Ed) 1981;282:1847-51
Sources of funding: NHS Centre for Reviews है Dissemination, University of York, UK; Health Education Authority, London, UK.

For correspondence: Professor S Ebrahim Epidemiology of Ageing, Social Medicine, University of Bristol, Canynge Hall, Whiteladies Road, Bristol BS8 2PR, UK $F A X+44(0) 117928$ 7325.

A modified version of this abstract appears in Evidence-Based Medicine and ACP Journal Club. 